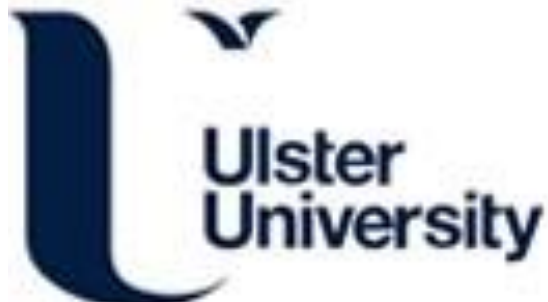

\section{FIBRILLATION FREQUENCY AND VENTRICULAR DEFIBRILLATION}

ALLEN, JD., STEWART, AJ., CARLISLE, EJF., Kernohan, G., \& ADGEY, AAJ. (1992). FIBRILLATION FREQUENCY AND VENTRICULAR DEFIBRILLATION. In J. P. Morucci, R. Plonsey, JL. Coatrieux, \& S. Laxminarayan (Eds.), Unknown Host Publication (Vol. 14, pp. 655-656). (PROCEEDINGS OF THE ANNUAL INTERNATIONAL CONFERENCE OF THE IEEE ENGINEERING IN MEDICINE AND BIOLOGY SOCIETY). IEEE.

Link to publication record in Ulster University Research Portal

Published in:

Unknown Host Publication

Publication Status:

Published (in print/issue): 01/01/1992

\section{Document Version}

Publisher's PDF, also known as Version of record

\section{General rights}

Copyright for the publications made accessible via Ulster University's Research Portal is retained by the author(s) and / or other copyright owners and it is a condition of accessing these publications that users recognise and abide by the legal requirements associated with these rights.

\section{Take down policy}

The Research Portal is Ulster University's institutional repository that provides access to Ulster's research outputs. Every effort has been made to ensure that content in the Research Portal does not infringe any person's rights, or applicable UK laws. If you discover content in the Research Portal that you believe breaches copyright or violates any law, please contact pure-support@ulster.ac.uk. 


\title{
Fibrillation Frequency and Ventricular Defibrillation
}

\author{
J. D. Allen, A. J. Stewart*, E. J. F. Carlisle*, W. G. Kernohan and A. A. J. Adgey* \\ Physiology and Orthopaedics, The Queen's University, and \\ Regional Medical Cardiology Centre, Royal Victoria Hospital*, \\ Medical Biology Centre, 97 Lisburn Road, Belfast BT9 7BL, N. Ireland.
}

\begin{abstract}
In a clinical study of 49 patients with acute ischemic heart disease poor success rates from ventricular defibrillation were associated with a low dominant frequency of ventricular fibrillation (generally $<5 \mathrm{~Hz}$ ) as determined by Fast Fourier Transform analysis of the body surface ECG. Experimental studies in the dog and pig are in accord with these observations, and indicate that the dominant frequency of ventricular fibrillation is reduced both by a long duration of fibrillation in a normal heart, and by some causes of ventricular fibrillation (ouabain or potassium toxicity in the dog, secondary fibrillation in man).
\end{abstract}

\section{INTRODUCTION}

Despite total disorganization of cardiac mechanical activity the characteristic ECG trace of ventricular fibrillation shows a continuous waveform with variable amplitude. When analysed by the Fast Fourier Transform much of the power of the signal resides in low frequency components, with a strongly dominant narrow waveband [1-3]. Is this dominant frequency of any significance for clinical resuscitation?

Since the introduction of cardiac defibrillation to clinical practice by Kouwenhoven, Beck, Zoll, Lown and their colleagues [4] considerable attention has focussed on improving the success rate for ventricular defibrillation. Various factors have been shown to be important, including the avoidance of delay in defibrillation, correction of acidosis, the maintenance of circulation by cardiac massage, and the amplitude of the ECG signal of ventricular fibrillation $[5,6]$.

\section{EXPERIMENTAL STUDIES}

The first experiments were undertaken in greyhound dogs $(21-35 \mathrm{~kg})$ anesthetized with sodium pentobarbitone $(30 \mathrm{mg} / \mathrm{kg}$ iv) and ventilated with room air [7]. The dominant frequency of the ECG at the body surface (Lead II) was $9.9 \pm 0.7 \mathrm{~Hz}$ (mean \pm S.E.M.), and fell with time, decreasing to $4-5 \mathrm{~Hz}$ after $90-120$ seconds of fibrillation. There was no early decline in fibrillation frequency in the endocardium [8]. Similar results were found for spontaneous and induced fibrillation during acute myocardial ischemia. However with fibrillation induced by toxic doses of ouabain $(7.1 \pm$
1.1 Hz) and by the administration of potassium $(4.8 \pm$ $0.8 \mathrm{~Hz}$ ) the frequency of fibrillation was significantly reduced. Clinically these 2 situations cause ventricular fibrillation which is difficult to abolish.

With continued ventricular fibrillation for 90 seconds the success rates for defibrillation with a 50 Joule shock were decreased in a further study, compared with those for short - duration fibrillation ( $<10$ seconds). Higher stored energies did not increase the defibrillation success rate.

Similar studies were undertaken in pigs $(30-45$ $\mathrm{kg}$ ) anesthetized with azaperone and pentobarbitone (30 $\mathrm{mg} / \mathrm{kg}$ ). The dominant frequency of fibrillation induced by electrical stimulation of the right ventricular endocardium was similar $(11.1 \pm 0.5 \mathrm{~Hz} ; 13$ pigs, 33.5 $\pm 1.1 \mathrm{~kg}$ weight) to that in the dogs, and showed a progressive fall with duration of fibrillation greater than 5 mins $(4.3 \pm 0.4 \mathrm{~Hz}$ at $10 \mathrm{mins})$. However, in contrast with the dogs, the fibrillation frequency showed a similar frequency and time-course in the endocardium and at the body surface throughout the period of observation.

\section{Clinical STUDIES}

What happens during ventricular fibrillation in man? Fast Fourier transform analysis of the ECG recordings of the first 8 seconds of ventricular fibrillation was undertaken in 49 patients (Bruel and Kjaer spectrum analyser). These patients were under observation prior to the onset of ventricular fibrillation, either in the Mobile Coronary Care Unit or in the hospital Coronary Care Unit. The body surface ECG was continuously digitized (10 bits and $240 \mathrm{~Hz}$ ) with an anti-aliasing filter $(44 \mathrm{~Hz})$, recorded on magnetic tape during fibrillation and resuscitation, and later analyzed.

The dominant frequency of ventricular fibrillation (VF) was significantly higher in the primary VF group $(5.18 \pm 0.3 \mathrm{~Hz} ; 33$ patients) when compared with the secondary VF group $(3.95 \pm 0.3 \mathrm{~Hz} ; 16$ patients; $\mathrm{p}<$ 0.05).

The resuscitation success rate was also higher in the primary VF group (20 of $33 ; 60.6 \%$ ) compared with the secondary VF group (4 of $16 ; 25 \% ; \mathrm{p}<0.05$ ). 
In the primary VF group, when the dominant frequency of VF was above $5 \mathrm{~Hz}(\mathrm{n}=20)$ the resuscitation success was $95 \%$, but only $7.7 \%$ when the dominant frequency was $5 \mathrm{~Hz}$ or below $(\mathrm{n}=13)$. In this group of 13 patients, with a low frequency of fibrillation, the dominant frequency of VF was highly correlated with the estimated duration of ventricular fibrillation $(r=-0.78 ; p$ $<0.05$ ).

\section{Conclusions}

Hence a decrease in the success of clinical defibrillation was observed when the frequency of VF was $5 \mathrm{~Hz}$ or less. Together the clinical and experimental data suggest that myocardial deterioration can be assessed by frequency analysis of ventricular fibrillation. Whether fibrillation frequency is a primary factor in poor resuscitation success, or an indicator of adverse electrophysiological and metabolic conditions in the myocardium remains to be established.

\section{ACKNOWLEDGMENT}

\author{
A.J.S. and E.J.F.C. held Royal Victoria Hospital \\ Research Fellowships.
}

\section{REFERENCES}

1. Nygards ME, Hulting J, "Recognition of ventricular fibrillation utilizing the power spectrum of the ECG," IEEE Computers in Cardiology, pp. 393-397, 1977.

2.Herschleb JN, Heethar RM, van der Tweel I, Zimmerman ANE, Meijler FL, "Frequency analysis of the ECG before and during ventricular fibrillation," IEEE Computers in Cardiology, pp. 365:368, 1980.

3. Martin G, Cosin J, Such M, Hernandez A, Llamas P, "The relation between power spectrum time course during ventricular fibrillation and electro-mechanical dissociation. Effects of coronary perfusion and nifedipine," Eur. Heart J., vol. 7, pp. 560-569, 1986.

4. Kouwenhoven WB, "The development of the defibrillator," Ann. Intern. Med., vol. 71, pp 449-457, 1969.

5. Gascho JA, Crampton RS, Cherwek ML, Sipes JN, Hustert P, O'Brien WM, "Determinants of ventricular defibrillation in adults," Circulation, vol. 60, pp. 231-2, 1979.

6. Weaver WD, Cobb LA, Dennis D, Ray R, Hallstrom AP, Copass MK, "Amplitude of ventricular fibrillation waveform and outcome after cardiac arrest," Ann. Intern. Med., vol. 102, pp. 53-55, 1985.

7. Carlisle EJF, Allen JD, Kernohan WG, Anderson J, Adgey AAJ, "Fourier analysis of ventricular fibrillation of varied aetiology," Eur. Heart J., vol. 11, pp. 173-181, 1990.

8. Worley SJ, Swain JA, Colavita PG, Sinith WM, Ideker RE, "Development of an endocardial - epicardial gradient of activation rate during electrically - induced, sustained ventricular fibrillation in dogs," Amer. J. Cardiol., vol. 55, pp. 813-820, 1985. 